\title{
Direct Organogenesis from Cotyledonary Node Explants of Cucurbita pepo (L.)-An Important Zucchini Type Vegetable Crop
}

\author{
Muruganantham Mookkan1,2,3 \\ ${ }^{1}$ Department of Plant Pathology and Weed Science, ARO Volcani Center, POB6, Bet Dagan, Israel \\ ${ }^{2}$ Department of Horticulture, University of Georgia, Tifton, GA, USA \\ ${ }^{3}$ Present Address and Correspondence: Division of Plant Sciences, University of Missouri, Columbia, Missouri, \\ USA \\ Email: mookkanm@missouri.edu
}

Received 18 December 2014; accepted 1 January 2015; published 15 January 2015

Copyright (C) 2015 by author and Scientific Research Publishing Inc.

This work is licensed under the Creative Commons Attribution International License (CC BY).

http://creativecommons.org/licenses/by/4.0/

(c) (i) Open Access

\begin{abstract}
Cotyledonary node explants from 3 - 5-d-old seedling derived explants of Cucurbita pepo (L.) produced multiple shoots in Murashige and Skoog (MS) salts B5 vitamins containing medium in the presence of N6-benzylamino-purine BAP $1 \mathrm{mg} / \mathrm{L}+$ Thidiazuron TDZ $0.05 \mathrm{mg} / \mathrm{L}$. After 4 weeks explants were subcultured to medium containing MS salts B5 Vitamins BAP $0.5 \mathrm{mg} / \mathrm{L}$, Gibberellic acid $\mathrm{GA}_{3} 1 \mathrm{mg} / \mathrm{L}$ and L-Glutamine $15 \mathrm{mg} / \mathrm{L}$. Periodic excision of regenerated shoots from the explants increased shoot efficiency during subculture. The combination of L-Glutamine with BA and $\mathrm{GA}_{3}$ significantly increased the shoot proliferation. Elongated shoots were excised from shoot clumps and transferred to rooting medium containing indole-3-butyric acid (IBA, $1.0 \mathrm{mg} / \mathrm{L}$ ). The rooted plants were hardened in small pot containing standardized garden soil, well developed plant transferred to greenhouse and survival rate was $85 \%$.
\end{abstract}

\section{Keywords}

Cucurbita pepo, Zucchini, Cotyledonary Node, Subculture

\section{Introduction}

The Cucurbita genus, of American origin, is one of the most variable genera within the Cucurbitaceae family [1]. The main economic value of the species resides in the consumption of its immature fruits as vegetables, com-

How to cite this paper: Mookkan, M. (2015) Direct Organogenesis from Cotyledonary Node Explants of Cucurbita pepo (L.)-An Important Zucchini Type Vegetable Crop. American Journal of Plant Sciences, 6, 157-162. 
monly known as summer squashes. Summer squashes of the Zucchini type rank among the highest-valued vegetables worldwide, whereas the "winter squash" types (fruits consumed when mature) of Cucurbita pepo and related Cucurbita spp. are food staples and rich sources of fat and vitamins in developing countries [2]. It has various medicinal effects comprising antidiabetic, antihypertensive, antitumor, antimutagenic, immunomodulating, antibacterial, anti-hypercholesterolemic, intestinal antiparasitic, antalgic, and anti inflammation effects, and utilization possibilities of various Cucurbitaceae species have been reported [3]. A wide range of pathogens hamper the cultivation of $C$. pepo, with more than eight different viruses infecting the crop [4]. Among these viruses, Papaya rings pot virus (PRSV) and Zucchini yellow mosaic virus (ZYMV) are the most important due to their prevalence and the degree of damage caused, which reduces crop and fruit quality. The control of these viruses is difficult and conventional breeding has not succeeded in producing new varieties with resistance to more than one virus species [5]. The development of tissue culture protocols is one of the solutions to address these problems.

In early reported regeneration via somatic embryogenesis in C. pepo [6]-[10]. Due to the difficulties in obtaining and longtime culturing somatic embryos, alternative protocols for direct or indirect organogenesis have been studied. Direct regeneration in C. pepo was first described using cotyledon with attached hypocotyl as explant [11]. A wide range of other $C$. pepo cultivars regenerate to the same extent (with one exception) using the same technique [12]. Brief sonication treatment stimulate shoot regeneration reported [13]. In vitro shoot regeneration of a seedling-derived organ caused by prolonged seed storage period reported [14]. The objective of this study was to investigate the effect of age of the explant, effect of important additives and subcultures to improve the regeneration from cotyledonary node explants of important zucchini type vegetable crop.

\section{Materials and Methods}

Seeds of C. pepo (Dark Green Zucchini) were purchased from the Reimer Seeds, Saint Leonard, MD. Mature seeds were soaked for 15 - 30 min in regular tap water and seed coats removed with forceps. The pealed seeds were then washed for $1 \mathrm{~min}$ in $70 \%$ ethanol and rinsed 3 times with sterile water. Then pealed seeds were treated with $2 \%$ chlorine solution ( 2 - 3 drops with Tween 20 ) for $20 \mathrm{~min}$. Then the seeds were washed with sterile water for 5 times. Sterilized pealed seeds were germinated, in $100 \times 20 \mathrm{~mm}$ petri dishes Murashige and Skoog (MS) medium [15] supplemented with $3 \%$ sucrose, $0.8 \%$ agar, and $\mathrm{pH} 5.7$ - 5.8. Five petri dishes were arranged in a plastic bag with four 1-inch slits for aeration. The plastic bag was tied strongly to prevent the lids from opening and also avoiding the contamination during the seed germination. Seeds were germinated for 5 days in a growth room. All the cultures at maintained under the white fluorescent light at a photon flux of $24 \mu \mathrm{mol} \cdot \mathrm{m}^{-2} \cdot \mathrm{S}^{-2}$ for $16 / 8 \mathrm{~h} \mathrm{light} /$ dark photoperiod at $25^{\circ} \mathrm{C} \pm 2^{\circ} \mathrm{C}$ and all media were sterilized at $120^{\circ} \mathrm{C}$ for $20 \mathrm{~min}$.

Explants were prepared from the 3 - 5-d-old C. pepo seedlings by making a horizontal slice through the hypocotyl region. A subsequent vertical cut was made between the (2 cotyledonary node explants) cotyledons, and the embryonic axis was removed then the cotyledon was cut in half and the distal parts discarded. Shoot induction medium tested individually containing MS medium, B5 vitamins, $3 \%$ sucrose, solidified $0.8 \%$ purified agar in $100 \times 20 \mathrm{~mm}$ Petri plates, supplemented with BA $0.5-2 \mathrm{mg} / \mathrm{L}$ or $\mathrm{KN}(0.5-2 \mathrm{mg} / \mathrm{L}$ or TDZ (0.01 - $0.1 \mathrm{mg} / \mathrm{L})$ and L-Glutamine $(5,10,15,20,25 \mathrm{mg} / \mathrm{L})$. On the other hand BA + TDZ + L-Glutamine or BA + KN + L-Glutamine combinations were tested. Explants with emerging shoots were subcultured in the same medium twice at the interval of 2 weeks each. Different concentrations of auxins (NAA/IAA) individually and in combination with BA were also tested for their shoot induction efficiency. Explants were cultured adaxialside up with the hypocotyl imbedded plates were wrapped with $3 \mathrm{M}$ pressure sensitive tape (ScotchTM, 3M, USA). After 14 days of culture, half hypocotyl region was excised from each of the explants, and the remaining explant was transferred to same medium. After 14 days the cotyledons were removed from the node carefully, remaining differentiating node subculture to same medium. Two weeks later explants were transferred to shoot elongation medium (SEM) containing MS salts, B5 vitamins BA $0.5 \mathrm{mg} / \mathrm{L}, 0.5 \mathrm{mg} / \mathrm{L}$ GA3, and $15 \mathrm{mg} / \mathrm{L}$ L-Glutamine. The explants were subculture by 12 - 14 days interval to fresh medium and follow the shoot elongation. Maximum 6 - 8 subsequent subcultures, the elongated single shoot $(2-3 \mathrm{~cm})$ were transferred to the rooting medium (RM) containing MS salts, B5 vitamins, $3 \%$ sucrose, $0.6 \%$ agar and $1 \mathrm{mg} / \mathrm{L}$ IBA in test tube. The rooted plants were transferred to the soil.

A complete randomized design was used in all experiments and analysis of variance and mean separations were carried out using Duncan's Multiple Range Test (DMRT). Statistical significance was determined at 5\% level. 


\section{Results and Discussion}

\subsection{Seed Germination}

Seed sterilization of $C$. pepo var. dark green germinated with seed coat directly on MS + B5 vitamins basal medium in petri plates or Majantha boxes showed 25\% - 40\% germination after 5 - 7 days, whereas $80 \%$ - 90\% was achieved uniform germination after 5 days if the after removal of seed coat on the B5 basal medium. The germination C. pepo pealed seeds on MS agar medium [9] and [11] has been reported.

\subsection{Effect of Cytokinin in Alone on Multiple Buds or Shoot Formation}

Cotyledonary node explants from 3 - 5 d-old seedlings were used as the explants. Adventitious buds were induced from the meristematic regions of cotyledonary node explants on MS medium supplemented with BA (0.5 - $2 \mathrm{mg} / \mathrm{L})$ or KN $(0.5-2 \mathrm{mg} / \mathrm{L})$ or TDZ $(0.01-0.2 \mathrm{mg} / \mathrm{L})$ after 2 weeks of culture. Axillary meristems of the cotyledonary node explants possess cell that are competent for regeneration and hence are considered as target tissue for gene delivery in legumes [16]. Shoot buds or shoots were formed from cotyledonary node explants with $1 \mathrm{mg} / \mathrm{L}$ BAP. Lower concentration BAP or KN (below $0.5 \mathrm{mg} / \mathrm{L}$ ) however, did not promote the shoot bud or shoots (data not shown). Among the three cytokinins the BA was more suitable than others. However, TDZ alone not promote the shoot formation. BA is the most widely used and most effective in cytokinin in various crops, requirement of BA for induction of multiple shoots has already been reported in C. pepo [11] and other cucurbitaceous family such as C. melo [17] C. sativus [18].

\subsection{Effect of Cytokinin Combinations on Multiple Shoot Formation}

TDZ was tested individually as well as combinations with BA. When using TDZ different concentrations alone did not promote more number of shoot buds or shoots (Table 1). Among the different concentrations TDZ 0.05

Table 1. Effect of plant growth regulators on multiple shoot induction from cotyledonary node explants of $C$. pepo cultured on MS medium.

\begin{tabular}{|c|c|c|c|}
\hline Growth regulators $(\mathrm{mg} / \mathrm{L})$ & Explants with shoots \% & Mean No. of shoots/explants & Callus formation \\
\hline \multicolumn{4}{|l|}{ BA } \\
\hline 0.0 & 0.0 & 0.0 & \\
\hline 0.5 & $68 \mathrm{f}$ & $4 \mathrm{c}$ & \\
\hline 1.0 & $90 \mathrm{~b}$ & $7 \mathrm{a}$ & \\
\hline 1.5 & $78 \mathrm{c}$ & $4.7 \mathrm{~b}$ & \\
\hline 2.0 & $55 \mathrm{j}$ & $3.5 \mathrm{~d}$ & \\
\hline \multicolumn{4}{|l|}{$\mathrm{KN}$} \\
\hline 0.5 & $60 \mathrm{~h}$ & $2.5 \mathrm{f}$ & \\
\hline 1.0 & $65 \mathrm{~g}$ & 3.0 e & \\
\hline 1.5 & $75 \mathrm{~d}$ & $4.0 \mathrm{c}$ & \\
\hline 2.0 & $55 \mathrm{j}$ & $2.4 \mathrm{~g}$ & \\
\hline \multicolumn{4}{|l|}{ TDZ } \\
\hline 0.01 & $58 \mathrm{i}$ & $1.8 \mathrm{~h}$ & \\
\hline 0.05 & $70 \mathrm{e}$ & $3.5 \mathrm{~d}$ & \\
\hline 0.1 & $55 \mathrm{j}$ & $1.5 \mathrm{i}$ & + \\
\hline 0.5 & $30 \mathrm{k}$ & $1.0 \mathrm{j}$ & ++ \\
\hline 1.0 & 0 & 0 & +++ \\
\hline \multicolumn{4}{|l|}{$\mathrm{BA}+\mathrm{TDZ}$} \\
\hline $1.0+0.05$ & 95 a & $12 \mathrm{a}$ & \\
\hline
\end{tabular}

Each value represents the treatment means of ten independent replicates. Values with the same letter within columns are not significantly different according to (DMRT) Duncan's Multiple Range Test at the 5\% level. 
with combination with BA $1 \mathrm{mg} / \mathrm{L}$ occurred shoot bud formation from the cotyledonary node explants after 2 weeks later. A maximum of 12 - 15 shoot buds/shoots per cotyledonary node explants were observed in MS + B5 medium fortified with combination of BA $1 \mathrm{mg} / \mathrm{L}$ and TDZ $0.05 \mathrm{mg} / \mathrm{L}$ at the end of second subculture. Highest shoot regeneration (85\%) and highest mean number of shoots (6.89) per culture was achieved in indirect shoot organogenesis in C. pepo reported [19] direct organogenesis in Cucumis sativus [20] and reported L. cylindrica [21]. Presence of BAP either alone or in combination with other cytokinins proved essential for direct as well as indirect shoot regeneration in cucurbits [22]. TDZ has been reported to be the best cytokinin to induce the maximum number of shoots in different plants such as A. sinuate [23] V. radiate [24] C. sativa [25] V. mungo [26]. However higher concentration of (above $0.5 \mathrm{mg} / \mathrm{L}$ with BA combination above $1.0 \mathrm{mg} / \mathrm{L}$ TDZ concentration with BA (1 mg/L), observed callus formation did not promoted the shoots.

\subsection{Effect of L-Glutamine with Cytokinin to Improve the Shoot Multiplication}

The addition of L-Glutamine was very useful for adventitious shoot regeneration in C. pepo. The highest frequency of adventitious shoot regeneration (above 90\%) and the maximum shoots/buds regeneration (20/explants) were achieved on MS medium containing BA, TDZ and $15 \mathrm{mg} / \mathrm{L}$ L-Glutamine at the end of second shoot induction. The shoot regeneration number per explants progressively decreased or callus formation with higher level of L-glutamine (data not show). The released nitrogen sources from L-glutamine provides a readily available source of nitrogen, the implication being that the formation of necessary carbon skeleton or the reduction of nitrate to ammonia is a limiting factor in the cells [27]. Maximum multiple shoot enhancement was observed in Cucumismelo [17], Cucumis sativus [28] due to the addition of glutamine. Our results showed that the improvement of in vitro multiple shoot buds/regeneration as well as improve the shoot number per cotyledonary node explants can be achieved by using BA TDZ with combination of L-Glutamine.

\subsection{Effect of Subculture on Shoot Elongation Medium and Shoot Production}

After 4 weeks of the culture the explants further transferred to the shoot elongation medium containing reduced concentration of BA $0.5 \mathrm{mg} / \mathrm{L}$ GA3 $0.5 \mathrm{mg} / \mathrm{L}$ with $15 \mathrm{mg} / \mathrm{L} \mathrm{L}$-glutamine. For this combination was used for all the subcultures. During the subculture the newly shoot buds are formatted and also observed clustered shoots. Similar reports were reported in C. pepo [11]. During the subculture rarely in vitro flowering are formed, precocious flowering is well known phenomenon in cucurbits [29]. Interestingly we observed continuous new bud, shoot formation in the elongation medium and the same time older shoots are elongated. Maximum shoots production observed at the end of culture/end of $8^{\text {th }}$ subculture 34 - 36 shoots/explant (Table 2). However, without BA and L-glutamine in the elongation medium shoot produced are reduced.

\subsection{Rooting and Hardening of Plants}

Rooting step is one of the very important in plant tissue culture techniques. During the elongation process the shoot elongation was occurred. Above $2-3 \mathrm{~cm}$ elongated shoot were transferred to the shoot induction medium containing MS salts with 1mg/L IBA. IBA is widely used for root induction in cucurbits [30] Maximum percentage of rooting (100\%) was found with $1.0 \mathrm{mg} / \mathrm{L}$ IBA in the present study (Table 3). Well rooted plants trans-

Table 2. Effect of L-Glutamine with the combination of BA $0.5 \mathrm{mg} / \mathrm{L}$, GA3 $1 \mathrm{mg} / \mathrm{L}$ on multiple shoot production and elongation.

\begin{tabular}{ccccc}
\hline $\begin{array}{c}\text { L-glutamine } \\
\mathrm{mg} / \mathrm{L}\end{array}$ & $\begin{array}{c}\text { \% of shoot } \\
\text { regeneration/explant }\end{array}$ & $\begin{array}{c}\text { No. of } \\
\text { shoots/explant }\end{array}$ & $\begin{array}{c}\text { New buds/shoots formation } \\
\text { in the same explant }\end{array}$ & $\begin{array}{c}\text { Total No. of shoots multiplication/explant } \\
\text { at the end of subculture/culture }\end{array}$ \\
\hline 0 & $65 \mathrm{e}$ & $8.2 \mathrm{f}$ & $1-3 \mathrm{f}$ & $10-12 \mathrm{e}$ \\
5 & $70 \mathrm{~d}$ & $10.4 \mathrm{c}$ & $6-8 \mathrm{c}$ & $16-18 \mathrm{c}$ \\
10 & $80 \mathrm{c}$ & $12.5 \mathrm{~b}$ & $8-10 \mathrm{~b}$ & $20-22 \mathrm{~b}$ \\
15 & $97 \mathrm{a}$ & $22.7 \mathrm{a}$ & $12-14 \mathrm{a}$ & $34-36 \mathrm{a}$ \\
20 & $85 \mathrm{~b}$ & $10.1 \mathrm{~d}$ & $5-7 \mathrm{~d}$ & $15-17 \mathrm{~d}$ \\
25 & $60 \mathrm{f}$ & $8.4 \mathrm{e}$ & $2-4 \mathrm{e}$ & $10-12 \mathrm{e}$ \\
\hline
\end{tabular}

Each value represents the treatment means of ten independent replicates. Values with the same letter within columns are not significantly different according to (DMRT) Duncan's Multiple Range Test at the 5\% level. 
Table 3. Effect of IBA on root induction.

\begin{tabular}{ccccc}
\hline IBA mg/L & Days required for root induction & \% roots formation & No. of roots/shoot & Length of roots $(\mathrm{cm})$ \\
\hline 0.1 & $15 \mathrm{~d}$ & $55 \mathrm{e}$ & $5.2 \mathrm{e}$ & $3.5 \mathrm{~d}$ \\
0.5 & $12 \mathrm{c}$ & $75 \mathrm{c}$ & $7.2 \mathrm{c}$ & $4.0 \mathrm{~b}$ \\
1.0 & $7 \mathrm{a}$ & $100 \mathrm{a}$ & $9.8 \mathrm{a}$ & $4.7 \mathrm{a}$ \\
1.5 & $10 \mathrm{~b}$ & $98 \mathrm{~b}$ & $8.9 \mathrm{~b}$ & $3.8 \mathrm{c}$ \\
2.0 & $17 \mathrm{e}$ & $60 \mathrm{~d}$ & $6.5 \mathrm{~d}$ & $2.5 \mathrm{e}$ \\
\hline
\end{tabular}

Each value represents the treatment means of ten independent replicates. Values with the same letter within columns are not significantly different according to (DMRT) Duncan's Multiple Range Test at the 5\% level.

ferred to the small plastic pot filled with standardized garden soil for hardening. After 2 weeks hardened plants were transferred to the greenhouse and $85 \%$ of them survived. All the surviving plants reached maturity and produced viable seeds.

\section{Conclusion}

A simple, efficient, improved and reproducible direct regeneration protocol used cotyledonary node explant of $C$. pepo was developed from 3 - 5-d-old in vitro seedlings. This improved shoot regeneration system may contribute to the establishment of an Agrobacterium-mediated transformation system for C. pepo- an important Zucchini type vegetable crop.

\section{References}

[1] Esteras, C., Nuez, F. and Picó, B. (2012) Genetic Diversity Studies in Cucurbits Using Molecular Tools. In: Behera, T.K., Wang, Y.H. and Kole, C., Eds., Genetics, Genomics and Breeding of Cucurbits, New Hampshire, Science Publishers Inc, Enfield, 140-198.

[2] Ferriol, M. and Picó, B. (2008) Pumpkin and Winter Squash. In: Prohens, J. and Nuez, F., Eds., Handbook of Plant Breeding Vegetables I Part 4, Volume 1, Springer, Berlin, 317-349.

[3] Kostalova, Z., Hromadkova, Z. and Ebringerova, A. (2009) Chemical Evaluation of Seeded Fruit Biomass of Oil Pumpkin (Cucurbita pepo L. var. Styriaca). Chemical Paper, 63, 406-413. http://dx.doi.org/10.2478/s11696-009-0035-5

[4] Kurozawa, C. and Pavan, M.A. (1997) Doenças das cucurbitáceas. In: Kimathi, H., Amorin, L., Bergamin, Filho, A., Camargo, L. and Rezende, J., Eds., Manual de Fitopatologia, doenças das plantascultivadas, 3rd Edition, São Paulo, Editora Agronômica Ceres, 2, 325-337.

[5] Gaba, V., Zelcer, A. and Gal-on, A. (2004) Cucurbit Biotechnology-The Importance of Virus Resistance. In Vitro Cellular and Developmental Biology-Plant, 40, 346-358. http://dx.doi.org/10.1079/IVP2004554

[6] Jelaska, S. (1972) Embryoid Formation by Fragments of Cotyledons and Hypocotyls in Cucurbita pepo. Planta, 103, 278-280. http://dx.doi.org/10.1007/BF00386851

[7] Jelaska, S., Magnus, V., Seretin, M. and Lacan, G. (1985) Induction of Embryogenic Callus in Cucurbita pepo Hypocotyl Explants Byindole-3-ethanol and Its Sugar Conjugates. Physiologia Plantarum, 64, 237-242. http://dx.doi.org/10.1111/j.1399-3054.1985.tb02342.x

[8] Chee, P.P. (1991) Somatic Embryogenesis and Plant Regeneration of Squash Cucurbita pepo L. cv. YC 60. Plant Cell Reports, 9, 620-622. http://dx.doi.org/10.1007/BF00231801

[9] Chee, P.P. (1992) Initiation and Maturation of Somatic Embryos of Squash (Cucurbita pepo). HortScience, 27, 59-60.

[10] Gonsalves, C., Xue, B. and Gonsalves, D. (1995) Somatic Embryogenesis and Regeneration from Cotyledon Explants of Six Squash Cultivars. HortScience, 30, 1295-1297.

[11] Ananthakrishnan, G., Xia, X., Elman, C., Singer, S., Paris, H., Gal-On, A. and Gaba, V. (2003) Shoot Production in Squash (Cucurbita pepo) by in Vitro Organogenesis. Plant Cell Reports, 21, 739-746.

[12] Kathiravan, K., Vengedesan, G., Singer, S., Steinitz, B., Paris, H.S. and Gaba, V. (2006) Adventitious Regeneration in Vitro Occurs across a Wide Spectrum of Squash (Cucurbita pepo) Genotypes. Plant Cell, Tissue and Organ Culture, 85, 285-295. http://dx.doi.org/10.1007/s11240-006-9079-1

[13] Ananthakrishnan, G., Xia, X., Amutha, S., Singer, S., Muruganantham, M., Yablonsky, S., Fischer, E. and Gaba, V. 
(2007) Ultrasonic Treatment Stimulates Multiple Shoot Regeneration and Explant Enlargement in Recalcitrant Squash Cotyledon Explants in Vitro. Plant Cell Reports, 26, 267-276. http://dx.doi.org/10.1007/s00299-006-0235-1

[14] Amutha, S., Muruganantham, M., Ananthakrishnan, G., Yablonsky, S., Singer, S. and Gaba, V. (2009) Improved Shoot Regeneration Due to Prolonged Seed Storage. Scientia Horticulturae, 119, 117-119. http://dx.doi.org/10.1016/j.scienta.2008.07.027

[15] Murashige, M. and Skoog, F. (1962) A Revised Medium for Rapid Growth and Bioassays with Tobacco Tissue Cultures. Physiologia Plantarum, 15, 473-497. http://dx.doi.org/10.1111/j.1399-3054.1962.tb08052.x

[16] Muruganantham, M., Amutha, S., Selvaraj, N., Vengadesan, G. and Ganapathi, A. (2007) Efficient Agrobacterium-Mediated Transformation of Vigna mungo Using Immature Cotyledonary-Node Explants and Phosphinothricin as the Selection Agent. In Vitro Cellular \& Developmental Biology-Plant, 43, 550-557. http://dx.doi.org/10.1007/s11627-007-9060-7

[17] Muruganantham, M., Ganapathi, A., Selvaraj, N., Prem Anand, R., Vasudevan, A. and Vengadesan, G. (2002) Adenine Sulphate and L-Glutamine Enhance Multiple Shoot Induction from Cotyledon Explants of Melon (Cucumis melo L. cv. Swarna). Cucurbit Genetics Cooperative Report, 25, 22-24.

[18] Curuk, S., Elman, C., Schlarman, E., Sagee, O., Shomer, I., Cetiner, S., Gray, D.J. and Gaba, V. (2002) A Novel Pathway for Rapid Shoot Regeneration from the Proximal Zone of the Hypocotyl of Melon (Cucumis melo L.). In Vitro Cellular \& Developmental Biology-Plant, 38, 260-267. http://dx.doi.org/10.1079/IVP2001259

[19] Shakti, P.P., Iftikhar, A., Anisuzzaman, M., Kanak Kanti, S., Shamima Akhtar, S. and Mohammad Firoz, A. (2007) Indirect Organogenesis in Summer Squash Cucurbita pepo L. Turkish Journal of Agriculture and Forestry, 31, 63-70.

[20] Meng, Z. and Hongwen, C. (2001) Stimulatory Effects of Different Cytokinin on Direct Plant Regeneration from Cotyledon Explants in Cucumis sativus L. Cucurbit Genetics Cooperative Report, 24, 13-16.

[21] Sujatha, D., Ravi, C., Raghuvardhan, L., Prasad, B., Gulab, K.R., Sadanandam, A. and Christopher, R.T. (2013) In Vitro Plantlet Regeneration and Genetic Transformation of Sponge Gourd (Luffa cylindrica L.). African Journal of Plant Science, 7, 244-252.

[22] Chaturvedi, R. and Bhatnagar, S.P. (2001) High Frequency Shoot Regeneration from Cotyledon Explants of Watermelon cv. Sugar Baby. In Vitro Cellular \& Developmental Biology-Plant, 37, 255-258. http://dx.doi.org/10.1007/s11627-001-0045-7

[23] Vengadesan, G., Ganapathi, A., Anand, R.P. and Selvarar, N. (2003) In Vitro Propagation of Acacia sinuata (Lour.) Merr. from Nodal Segments of a 10-Year-Old Tree. In Vitro Cellular \& Developmental Biology-Plant, 39, 409-414. http://dx.doi.org/10.1079/IVP2003421

[24] Amutha, S., Muruganantham, M. and Ganapathi, A. (2006) Thidiazuron-Induced High-Frequency Axillary and Adventitious Shoot Regeneration in Vigna radiate (L.) Wilczek. In Vitro Cellular \& Developmental Biology-Plant, 42, 26-30. http://dx.doi.org/10.1079/IVP2005721

[25] Lata, H., Chandra, S., Khan, I. and ElSohly, M.A. (2009) Thidiazuron-Induced High-Frequency Direct Shoot Organogenesis of Cannabis sativa L. In Vitro Cellular \& Developmental Biology-Plant, 45, 12-19. http://dx.doi.org/10.1007/s11627-008-9167-5

[26] Muruganantham, M. and Ganapathi, A. (2014) $\mathrm{AgNO}_{3}$ Boosted High-Frequency Shoot Regeneration in Vigna mungo (L.) Hepper. Plant Signaling and Behavior, 9, e972284. http://dx.doi.org/10.4161/psb.32165

[27] Bayley, J.M., King, J. and Gamborg, O.L. (1972) The Effect of the Source of Inorganic Nitrogen on Growth and Enzymes of Nitrogen Assimilation in Soybean and Wheat Cells in Suspension Cultures. Planta, 105, 15-24. http://dx.doi.org/10.1007/BF00385159

[28] Selvaraj, N., Vengadesan, G., Vasudevan, A., Prem, A.R., Ramesh, A.V. and Ganapathi, A. (2002) Micropropagation of Cucumis sativus L. from Field Grown Plants. In: Maynard, D.N., Ed., Proceedings of the Cucurbitaceae, ISHS Press, Belgium, 149-156.

[29] Wang, S., Tang, L. and Chen, F. (2001) In Vitro Flowering of Bitter Melon. Plant Cell Reports, 20, 393-397. http://dx.doi.org/10.1007/s002990100351

[30] Sarowar, S., Oh, H.Y., Hyung, N.I., Min, B.W., Harn, C.H., Yang, S.K., Ok, S.H. and Shin, J.S. (2003) In Vitro Micropropagation of a Cucurbita Interspecific Hybrid Cultivar-A Root Stock Plant. Plant Cell, Tissue and Organ Culture, 75, 179-182. http://dx.doi.org/10.1023/A:1025043130423 
Scientific Research Publishing (SCIRP) is one of the largest Open Access journal publishers. It is currently publishing more than 200 open access, online, peer-reviewed journals covering a wide range of academic disciplines. SCIRP serves the worldwide academic communities and contributes to the progress and application of science with its publication.

Other selected journals from SCIRP are listed as below. Submit your manuscript to us via either submit@scirp.org or Online Submission Portal.
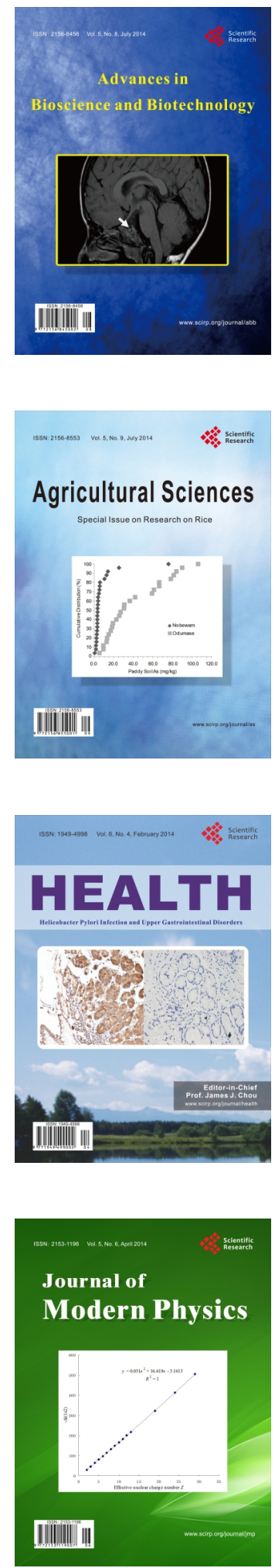
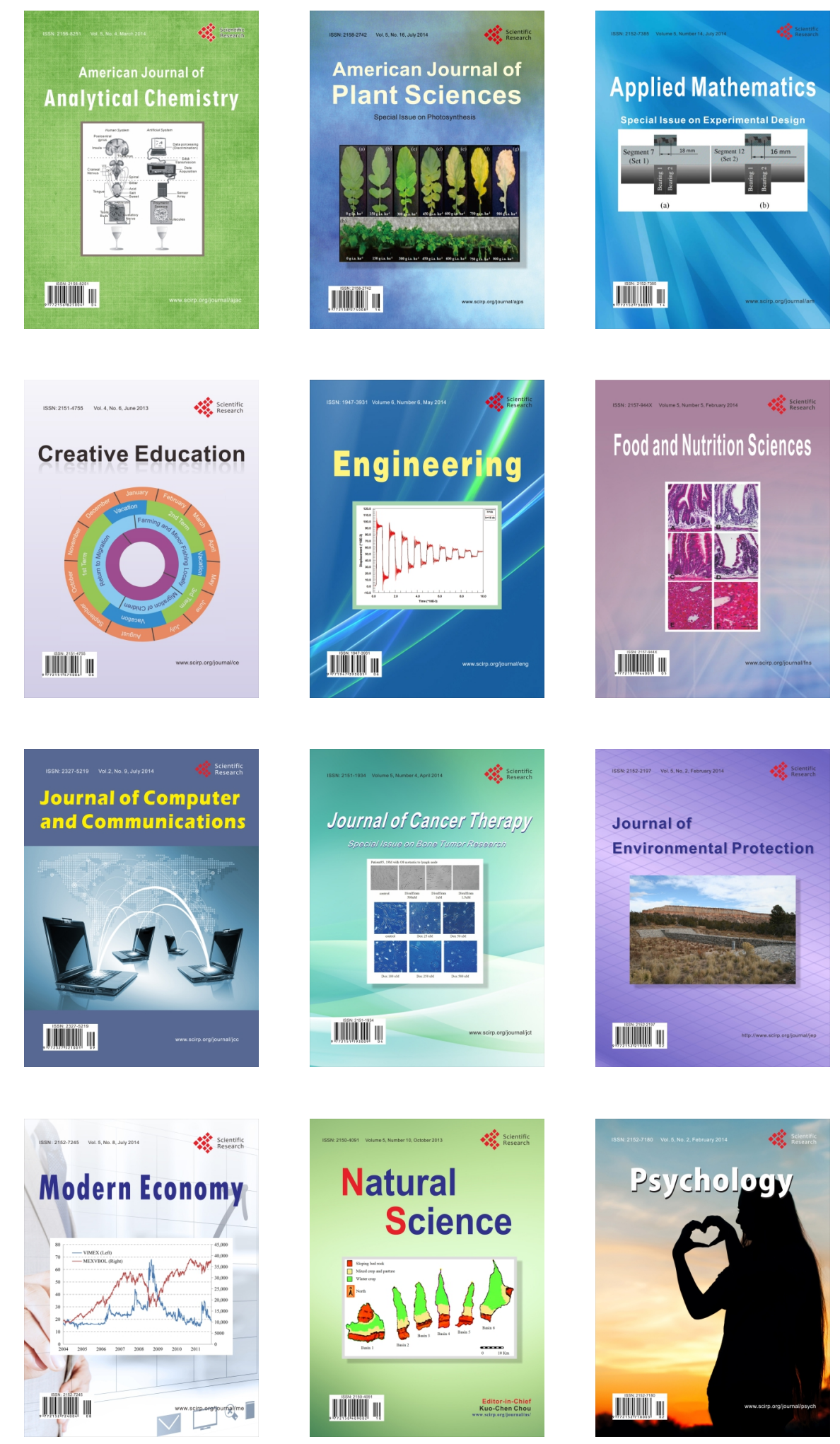